\title{
THE HUMAN FACTOR IN ARGENTINE AGRICULTURE $^{\circ}$
}

\author{
EL RECURSO HUMANO EN LA AGRICULTURA ARGENTINA
}

Marcos Gallacher*

enviado: 15 noviembre 2020 - aprobado: 08 marzo 2021

\section{Resumen}

El objetivo de este trabajo es identificar los determinantes de la reducción de uso del factor trabajo en el sector agropecuario argentino. Se focaliza la atención en los años 2002-2018, período comprendido entre los dos últimos Censos Nacionales Agropecuarios que presentan resultados confiables (el CNA 2008 quedó incompleto). La investigación pasa revista a las tendencias en cuanto a uso de trabajo y tamaño de empresa en Argentina, y presenta tres posibles hipótesis que explican los cambios observados: (a) sustitución de trabajo por capital, (b) cambio tecnológico ahorrador de mano de obra (labranza reducida y siembra directa) y (c) cambio en el tamaño de empresa y en el tipo de capital (maquinarias) utilizadas.

Códigos JEL: Q1, D2.

Palabras clave: trabajo en el sector agropecuario argentino, elasticidad de sustitución.

\begin{abstract}
The objective of this paper is to identify determinants of the reductions in the use of labor observed in Argentine agriculture. The paper focuses on the 2002-2018 period, using data from the last two publications of the Censo Nacional Agropecuario (the census undertaken in 2008 is incomplete). The paper summarizes trends of labor use and firm size in Argentina, and presents three possible hypothesis accounting for the observed changes: (a) capital-labor substitution, (b) labor-saving

Gallacher, M. (2021). The human factor in Argentine agriculture. Estudios económicos, 38(77), pp. 39-63. DOI: https://doi.org/10.52292/j.estudecon.2021.2269

* University of CEMA, Argentina. ORCID: https://orcid.org/0000-0002-9548-9966.

E-mail: gmg@cema.edu.ar
\end{abstract}


technical change (reduced and no-tillage), and (c) changes in the farm size and the types of capital (machines) used.

JEL Codes: Q1, D2.

Keywords: labor in the Argentine agricultural sector, elasticity of substitution. 


\section{INTRODUCTION}

Since the early 1960s, Argentine agriculture experienced considerable growth. This contrasts with the relatively poor performance of previous decades. The output growth resulted from a steady stream of new technologies, which included new wheat varieties, sunflower hybrids, the introduction of the soybean crop (1960s and early 1970s), an increased use of fertilizers (1980s), and a rapid adoption of no-till production methods in the 1990s. The latter technology allows a reduction in the costs of production as well as an improved soil management. It also triggered a substantial shift of land from livestock to crop production, in particular in areas previously considered "marginal" for crops (for a comprehensive survey of production technology in the Argentine agricultural sector, see Andrade, 2017).

The Argentine agricultural sector is highly heterogeneous, including both "extensive" crops such as cereals and oilseeds, and "intensive" fruit and vegetable production. More than three-quarters of output corresponds to the production of cereal, oilseed, beef, dairy, and poultry. Heterogeneity in outputs and in the agronomic conditions results in a wide variety of input combinations being used: labor share in total costs range from less than $10 \%$ in cereal and oilseed crops to more than $50 \%$ in fruits and vegetables.

The objective of this paper is to identify forces affecting labor use in the Argentine agricultural sector. While several studies have outlined the general input and output trends in the Argentine agriculture, the "human factor" has received minor attention.

The process of economic development results in the substitution of other inputs for labor, as well as a "technological change" that allows increased output to be produced with the same input levels. A reduction in labor use in agriculture occurs simultaneously with changes in the types of labor employed. Shifts in the demand for skills resulting from new technologies increase returns to managerial ability and, thus, the quantity supplied of both managerial as well as operator knowhow. Evidence of the impact of human capital in agriculture is abundant (see e.g., Evenson, 1988; for Argentina, Gallacher, 2010; Gallacher, 2012; and Gallacher and Lema, 2018). In the case of Argentina, data limitations restrict "what can be learned" in relation to the labor input in agriculture. ${ }^{1}$ With this caveat, the following are some of the relevant issues related to the "human factor" that merit attention:

1 The term "labor" is used here somewhat loosely, including both "workers" and managers/entrepreneurs. Unless otherwise stated, "labor" and "human factor" will be thus used interchangeably to refer to various inputs of human effort. 
1. To what extent is the agricultural sector becoming less "labor dependent": i.e., are production processes tending towards lower ratios between labor and other inputs?

2. How responsive is the ratio between labor and other inputs to relative price changes: i.e., are we able to understand the relevant elasticity of substitution? How is the elasticity of substitution affected by the characteristics of the technology used in the production?

3. How does the marginal productivity of the labor input compare to the relevant factor price: is disequilibrium the norm, suggesting continued labor out-migration?

4. What changes are occurring in the types of labor inputs used: is increasing human capital evident?

5. What complementary relations exist between the on-farm labor input and the supply of off-farm know-how (public extension services, private advisors)?

Items (1) - (5) include an ambitious research agenda, and are listed here only as a "road map" of the issues that merit attention. This paper will focus on items (1) and (2).

\section{LABOR USE TRENDS}

The falling share of agriculture in the economy-wide employment is a wellestablished fact for most countries. For the Latin American and the Caribbean region, the World Bank data (World Development Indicators [WDI]) show a decline in the share of agricultural labor over the total labor from $20.8 \%$ in 1995 to $13.7 \%$ in 2019. For the OECD countries, relevant data are $8.5 \%$ and $4.8 \%$, respectively. For the U.S., an advanced economy with an export-oriented agricultural sector, the reduction was from $1.7 \%$ in 1995 to less than $1.4 \%$ in 2019. Figures for Canada and Australia suggest a similar pattern to that found in the U.S. Middle and low-income economies report considerably higher labor employment shares, but these are also characterized by a declining trend. WDI agricultural labor data for Argentina are not trustworthy: according to this source, for recent years, labor shares fell well below $0.1 \%$, an unreasonable figure given the observed trends in other countries. ${ }^{2}$ The wide range of existing estimates is highlighted by comparing the WDI data mentioned above (less than $0.1 \%$ of employment) with, for example, that reported

2 Labor surveys are conducted in metropolitan areas, thus excluding rural residents. 
by a private think-tank according to which jobs in the primary agricultural sector are about $9.5 \%$ of the total jobs in the country (Pisani Claro \& Mazo, 2019) ${ }^{3}$.

A first approximation to labor use trends (as opposed to absolute values) in agriculture can be obtained by considering the evolution of population residing in rural areas. If the ratio of agricultural employment to rural area population remains fairly constant over time, the rural population trends may suggest - if not absoluteat least agricultural employment trends. As shown in Figure 1, the rural population as a fraction of the total population in Argentina decreased continuously over time, from approximately $30 \%$ in the late 1950 s to $8.2 \%$ in 2019 . In the period analyzed, the reduction in the rural population seems to have slowed down significantly from a fall of 7-8 percentage points per decade in the 1950 s to less than 1.5 percentage points in the last decade of the series. For 2018, the rural/total population ratio was $8.2 \%{ }^{4}$

Figure 1. Argentina. Rural/Total Population

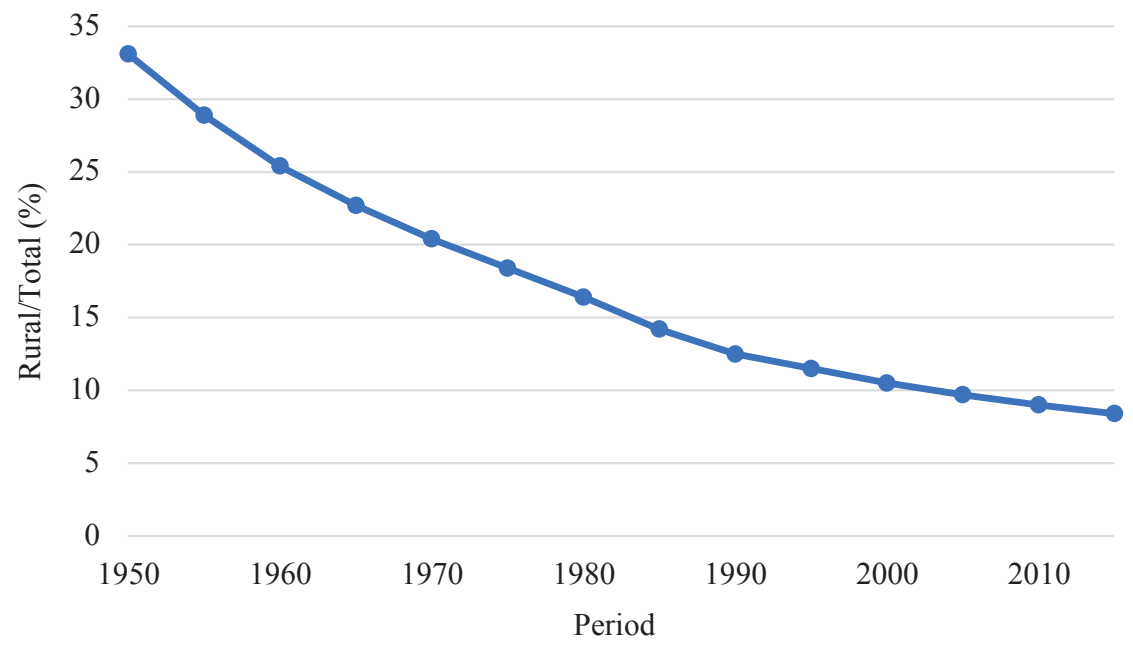

Source: FAOSTAT.

Urban Population: residing in towns/cities $>2000$ inhabitants.

Rural Population: Total - Urban.

3 The FADA report estimates employment by using data on "sector-specific jobs" produced by a government agency.

4 According to INDEC, "urban" population refers to the population residing in rural areas or towns of more than 2000 inhabitants. The "rural" population is the difference between the total population and the urban population. 
The national employment figure for 2018 was 18.8 million. Assuming an identical labor force participation in rural and urban areas, this results in 1.54 million workers residing in rural areas. Taking this figure as a starting point, the estimation of workers engaged in primary production requires data on:

1. Workers in non-rural areas engaged in primary ag production.

2. Decomposition of the 1.54 million workers residing in rural areas into:

i. Primary ag production.

ii. Workers not engaged in primary ag production. This includes both ag as well as non-ag related activities.

The above only suggests data needs involved in estimating labor input in the primary agricultural sector, but it does not allow progress in obtaining relevant figures. However, it indicates possible shifts in occupational patterns through time ${ }^{5}$. In particular:

1. Allocation of labor between (i) primary agricultural production, (ii) agrelated, but not the primary one; and (iii) non-ag activities depending on several factors. If the elasticity of substitution between labor and capital substitution is higher in (i) than in (ii) or (iii), labor should migrate accordingly. However, the ease of substitution is not the only factor: the increased local demand for non-agricultural output, as compared to the agricultural one (export + domestic), plays an additional role6.

2. In relation to the last point, during the last decade, municipal employment increased by $40 \%$ (Susmel, personal communication, 2020), resulting in additional competition for labor with agricultural-related activities. This factor is particularly important in areas where labor-intensive activities take place, and may account for part of the reduction in labor allocated to agriculture.

Census data do not report labor hours allocated to agriculture. Estimating labor use is further complicated by the fact that a considerable portion of the crop area receives labor services in the form of custom work from contractors not classified as "farmers." Thus, these services should be added to the existing on-farm labor services (see Appendix for calculations).

5 For a recent discussion of rural labor markets, see International Labor Organization (2020).

6 Of course, labor mobility is not restricted to "local" areas (rural and non-rural), but includes the possibility of substantial geographical re-location. 
For the selected provinces and the country as a whole, Table 1 shows an estimate of labor use changes between the 2002 and 2018 censuses. This estimate was derived by adding reported permanent farm labor to an estimate of personyears of labor provided by contractors. Labor is measured by headcount and not by the most appropriate labor-hours metric. Available evidence thus points to $38 \%$ of country-wide reduction in labor input, ranging from $23 \%$ in the pradera pampeana to $52 \%$ in the non-pampean area. These averages mask considerable disparities in the fall in labor-use, from a minimum of $12 \%$ in La Pampa to $69 \%$ in Tucumán.

Table 1. Labor in Primary Agricultural Production (Labor on farms + estimate of labor provided by contractors)

\begin{tabular}{|c|c|c|c|}
\hline & 2002 & 2018 & $\%$ Change \\
\hline & & & Labor \\
\hline & $(\cdot 000)$ & $(\cdot 000)$ & \\
\hline Total & 819 & 504 & -0.38 \\
\hline \multicolumn{4}{|l|}{ "Pradera Pampeana" provinces: } \\
\hline Buenos Aires & 133 & 109 & -0.18 \\
\hline Cordoba & 74 & 60 & -0.19 \\
\hline Entre Rios & 46 & 29 & -0.37 \\
\hline Santa Fe & 69 & 48 & -0.30 \\
\hline La Pampa & 17 & 15 & -0.12 \\
\hline \multicolumn{4}{|l|}{ Selected "Zona Extra-Pampeana" provinces: } \\
\hline Chaco & 38 & 18 & -0.53 \\
\hline Salta & 29 & 18 & -0.38 \\
\hline Santiago del Estero & 56 & 27 & -0.52 \\
\hline Tucuman & 26 & 8 & -0.69 \\
\hline Total "Pradera Pampeana" & 341 & 263 & -0.23 \\
\hline $\begin{array}{l}\text { Total Selected "Zona Extra-Pampeana" } \\
\text { provinces }\end{array}$ & 151 & 72 & -0.52 \\
\hline Rest & 326 & 168 & -0.48 \\
\hline
\end{tabular}

Source: INDEC, Censo Nacional Agropecuario 2002 and 2018. 


\section{EXPLAINING THE REDUCTION IN THE USE OF THE LABOR INPUT}

Estimates presented above are crude: "permanent" labor as reported in the census hides the fact that the degree of utilization of this labor may have changed through time. As an example, if each of the remaining laborers supplied more labor hours in 2018 than in 2002, the $41 \%$ of country-wide reduction in reported labor (most of which is "permanent" labor) may over-estimate the actual reduction in labor services. ${ }^{7}$ The point made here is that disequilibrium may result in underutilization of labor stocks. Adjustment then takes place reducing labor stocks, with a resulting increase in labor flows from existing stocks. The "measured" reduction in labor use may then over-estimate the actual reduction. Despite these caveats, the evidence points out that a significant reduction in labor took place during the last decade and a half.

Three possible hypotheses may explain the reductions in the labor use observed during the last decade and a half in the Argentine agriculture:

1. H1: Capital (in particular, farm machinery) substituted for labor inputs.

2. H2: Technical change: widespread adoption of reduced tillage systems allowed savings in the labor input due to the considerably lower requirements per unit of cropland of reduced tillage systems, as compared to conventional ones.

3. H3: Economies of size: a reduction in labor requirement per unit of output as a consequence of growth in farm size with the corresponding higher labor-use efficiency (increased specialization, reduced inefficiencies due to "lumpiness").

\section{II.1. H1: Input Substitution}

Labor-use changes are a function of changes in the relative price of labor and (in particular) labor-saving capital inputs. The extent to which capital can substitute for labor depends on the technology of production. Operations such as planting, spraying, and harvesting of cereal and oilseed crops allow mechanization, while others, such as vegetable production labor inputs, are not so easily replaced

7 Allocation of time to off-farm work is an important issue to be addressed in future work. Preliminary analysis of this issue, however, suggests relatively modest changes in the proportion of producers reporting off-farm work. No information exists for off-farm work for family or hired labor. 
by machinery. A standard measure of the "ease" of substituting capital for labor inputs is the elasticity of substitution:

$$
\begin{gathered}
\sigma_{K L}=\% \Delta(K / L) / \% \Delta(w / r)= \\
=100 *\left\{\left[\left(K / L_{1}-(K / L)_{0}\right]\right.\right. \\
\left./\left[(w / r)_{1}-(w / r)_{0}\right]\right\}\left\{\left[(w / r)_{1}+(w / r)_{0}\right]\right. \\
\left./\left[(K / L)_{1}+(K / L)_{0}\right]\right\}
\end{gathered}
$$

where $w$ and $r$ denote wage and the price of capital services, respectively. Subscripts correspond to the two time periods considered here.

Ideally, $\sigma_{K L}$ should be estimated using econometric procedures. However, data availability precluded this approach from being used here. An attempt was then made to obtain a rough approximation to $\sigma_{\mathrm{KL}}$ by comparing changes in the $K / L$ ratio between two periods with changes in the relative prices faced by producers in those periods. We used the 2002 and 2018 censuses to obtain $K / L$ ratios for nine provinces of the main agricultural area of Argentina. The Appendix details the calculations involved in deriving relevant indices.

The capital input used in each period can be obtained - at least as a first approximation - in a relatively straightforward manner. A more significant problem arises in the measurement of labor: census data report labor stocks and not labor flows allocated to production. Sub-utilization of labor stocks can, therefore, be expected to bias the results: if sub-utilization has decreased over time, the "measured" changes in the use of labor will over-estimate the "real" changes in labor flows.

Additional issues emerge as relates to the relevant $w / r$ price ratio. First, data on agricultural wages are hard to obtain. Published data are based on very rough estimates and not on formal surveys. Furthermore, no dis-aggregation by geographical area is available, a significant source of bias given that agricultural labor markets are not perfectly integrated. Second, how do changing $w / r$ relative prices enter into the producers decision-making process? This is particularly important in a country such as Argentina, where a high and variable inflation results in significant ups and downs in real wages over time. Prices of capital inputs also experience changes due to variations in import tariffs, credit availability, and other factors. As a result, the producer can be expected to react in a parsimonious way to price signals received, in particular due to the significant time necessary to recoup 
funds invested in items such as tractors, combines, and other expensive pieces of machinery. Given the above, price ratios used here refer to averages of several years centered in the initial and in the final period analyzed.

Table 2 shows $w / r$ ratios resulting from three alternative methods of estimation (see Appendix for calculations). As shown, $\% \Delta(w / r)$ varies widely, ranging from a minimum of $20 \%$ to $80 \%$ of increase in the price of labor with respect to capital. This last figure appears unreasonably high, in particular given the poor performance of the Argentine economy in the period under consideration. The lower and upper bounds of $\% \Delta(\mathrm{w} / \mathrm{r})$ used here for discussion purposes are $20 \%$ and $60 \%$, respectively, although, again, $60 \%$ seems "far off" from what would be expected. As a compromise, values in the order of $30-40 \%$ increase in the price of labor with respect to capital can be taken as a starting point. ${ }^{8}$

Table 2. Changes in the $\mathrm{w} / \mathrm{r}$ Price Ratio

\begin{tabular}{lccc}
\hline Alternative w/r indexes & $\mathbf{2 0 0 2}$ & $\mathbf{2 0 1 8}$ & $\boldsymbol{\% \Delta ( w / r )}$ \\
\hline $\begin{array}{l}\text { Index 1: w/Tractor Price } \\
\text { Index 2: w/Non-Labor Machine }\end{array}$ & 0.11 & 0.20 & 62 \\
$\begin{array}{l}\text { Service Cost } \\
\text { Index 3: w/Non-Labor Machine }\end{array}$ & 40.40 & 94.76 & 80 \\
Service Cost & 1.8 & 2.2 & 20 \\
\hline
\end{tabular}

Index 1 and 2: data source "Márgenes Agropecuarios" publication.

Index 3: data source AACREA.

Calculations in the Appendix.

8 For the 1990-1993 period, Juan Luis Bour reported a reduction of 40\% in the price of capital with respect to labor. This was caused by the elimination of import tariffs and a fall in country risk, both of which resulted in a lower price of capital inputs. Bour's results highlight the significant changes in relative prices that characterize the Argentine economy. The period analyzed here (2002-2018) is - from a macroeconomic perspective - diametrically opposite to the 1990-1998 "convertibilidad" period. However, even allowing for errors in our calculations, the $w / r$ relative price seems to have also increased in 2002-2018. 
Table 3 shows estimates of $\sigma_{K L}$ for the country as a whole and for several provinces. The lower and upper bounds of $\% \Delta(w / r)$ are used to derive the relevant figures. Results can be summarized as follows. First, the country-wide estimate of $\sigma_{\mathrm{KL}}$ ranges from 0.9 to 2.6. The lower value of 0.9 is "close" to the elasticity of substitution resulting from the Cobb-Douglas functional form widely used in agricultural economics research. The elasticity of substitution is higher in the non-pampean provinces than in the pampean ones $(1.3-4.0$ for the former versus $0.6-1.7$ for the latter). This appears reasonable: labor "surplus" is probably higher in the non-pampean areas, resulting in increased opportunities for reduction of this input as additional capital becomes available. As partial evidence of the above, output per farm in 2002 of nonpampean areas was only a quarter of that observed in the pampean region, indicating both a smaller farm size as well as a lower productivity per unit of land. In 2018, the gap between these two regions had narrowed; still non-pampean output per farm was a third of that observed in the pampean region. Lower output per farm suggests (although not conclusively) lower returns to labor and management.

Figure 2 shows the estimated values for $\sigma_{K L}$ as a function of changes in the relative price ratio between labor and capital. The horizontal axis spans the lowest $(20 \%)$ and highest $(60 \%)$ bounds of the increase in the price of labor with respect to capital. The formula used to calculate $\sigma_{K L}$ is a hyperbola. As such, "errors" in estimating $\% \Delta(w / r)$ have a larger impact on the estimated $\sigma_{K L}$ at lower values as compared to higher ones of $\% \Delta(w / r)$. Using the average between the $\% \Delta(w / r)$ bounds shown in the graph, the estimated $\sigma_{K L}$ ranges from 0.8 in the pampean region to 2.0 in the non-pampean one, averaging 1.3 for the country as a whole. If somewhat smaller values for $\% \Delta(w / r)$ are used for the calculations $(e . g ., 30 \%)$, elasticity values range from 1.4 to 2.8 , with 1.9 for the country-wide average.

Empirical estimates of capital-labor substitution (Wei, 2013) show values for the elasticity of substitution ranging from 1 to 7 for Brazil and from 2.0 to 3.5 for the U.S. These cases are of interest, as the agriculture in both countries shares similarities with that found in Argentina. The substitution values reported in Table 3 appear, therefore, "reasonable", at least as compared with those reported in Wei's paper.

A further comment may be made on the calculations presented so far. Strictly speaking, the $\sigma_{K L}$ construct refers to movements along a given isoquant - output is kept constant. We have sidestepped this issue here: output increased significantly between the two periods analyzed. However, if output increases are "neutral" in the sense of not changing the marginal rate of substitution given a constant $K / L$ ratio, the estimated $\sigma_{K L}$ will not be affected. Additional comments on possible "non-neutrality" of technical change are presented below. 
Table 3. Elasticity of Substitution

\begin{tabular}{|c|c|c|c|c|c|}
\hline & \multicolumn{2}{|c|}{$K / L$} & \multirow{2}{*}{$\begin{array}{c}\Delta K / L(\%) \\
2002-2018\end{array}$} & \multirow{2}{*}{\multicolumn{2}{|c|}{$\begin{array}{c}\sigma_{K L} \\
\Delta w / r(\%)\end{array}$}} \\
\hline & 2002 & 2018 & & & \\
\hline & \multicolumn{2}{|c|}{ (K/L index) } & $\%$ & 20 & 60 \\
\hline Total & 40425 & 68615 & 52 & 2.6 & 0.9 \\
\hline \multicolumn{6}{|c|}{ “Pradera Pampeana" provinces: } \\
\hline Buenos Aires & 66678 & 84377 & 23 & 1.2 & 0.4 \\
\hline Córdoba & 75910 & 110114 & 37 & 1.8 & 0.6 \\
\hline Entre Ríos & 52116 & 91357 & 55 & 2.7 & 0.9 \\
\hline La Pampa & 16040 & 27343 & 52 & 2.6 & 0.9 \\
\hline Santa Fe & 323281 & 366790 & 13 & 0.6 & 0.2 \\
\hline \multicolumn{6}{|c|}{$\begin{array}{l}\text { Selected "Zona Extra-Pampeana" } \\
\text { provinces: }\end{array}$} \\
\hline Chaco & 35524 & 81278 & 78 & 3.9 & 1.3 \\
\hline Salta & 17964 & 31779 & 56 & 2.8 & 0.9 \\
\hline Santiago del Estero & 9654 & 33596 & 111 & 5.5 & 1.8 \\
\hline Tucumán & 35412 & 91774 & 89 & 4.4 & 1.5 \\
\hline Total "Pradera Pampeana" & 69278 & 96811 & 33 & 1.7 & 0.6 \\
\hline $\begin{array}{l}\text { Total Selected "Zona Extra- } \\
\text { Pampeana" provinces }\end{array}$ & 22364 & 51779 & 79 & 4.0 & 1.3 \\
\hline
\end{tabular}

Source: INDEC - Censo Nacional Agropecuario 2002 and 2018. 
Figure 2. $\sigma_{\mathrm{KL}}$ as a Function of $\% \Delta(\mathrm{w} / \mathrm{r})$

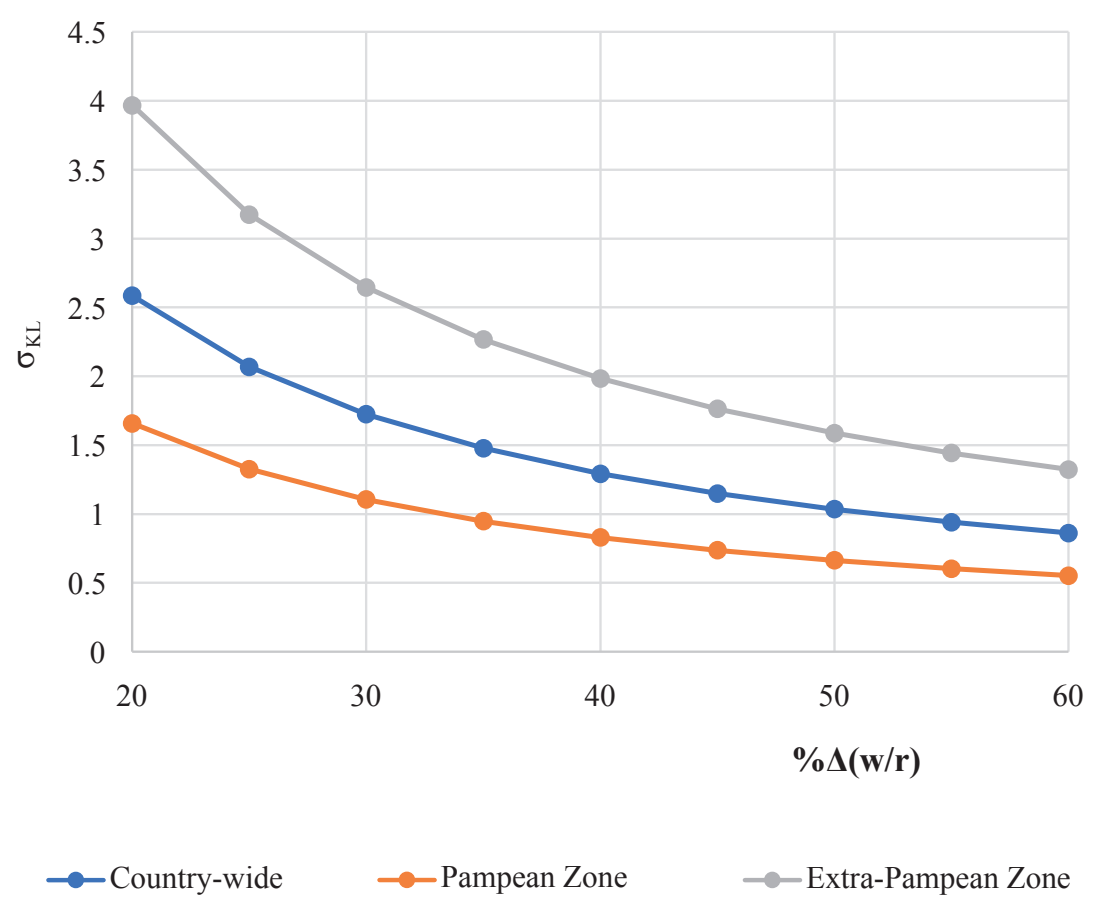

Source: Own calculations.

In sum, the reported increase in the price of labor with respect to capital is a strong candidate in explaining the reductions observed in the use of labor input in the Argentine agriculture. Given the higher estimated values $\sigma_{K L}$ for non-pampean areas, the increased use of capital as a determinant of the reduction in labor use appears particularly important in these regions, as compared to the pampean areas of the country.

\section{II.2. H2: Labor-Saving Technical Change}

The adoption of reduced and zero-tillage is a plausible candidate for the observed reductions in labor use: for cereals and oilseeds, this technology reduces the number of operations during the cropping season. The use of reduced and zero-tillage increased from less than $5 \%$ of planted acreage in the 1990 s to $55 \%$ in 
2002 and 90\% in 2018 (Nocelli Pac, 2018). The extensive use of this technology was possible due to the introduction of herbicide resistant seeds, in particular in the soybean and corn crops.

The "net" effect of reduced tillage systems can be expressed as the sum of the "substitution" effect caused by a lower labor requirement per unit of area of reduced tillage, as compared to the conventional one, plus the "expansion effect" associated with changes in the crop area induced by the reduced tillage technology.

The substitution effect $\Delta L^{S}$ represents the impact of reduced tillage from $\mathrm{t}=2002$. It is calculated as the difference between labor requirements given the shares of conventional and reduced tillage existing in 2002 and 2018, given the 2002 planted area. In turn, the expansion effect $\Delta L^{E}$ is the difference between the extra labor resulting from the expansion in the crop area and the reduction in labor that follows from the lower livestock numbers caused by the re-allocation of land from livestock to crop production.

Table 4 shows the total crop area and the area under the conventional and reduced tillage systems in the two periods considered here. The reported figures correspond to the most important crops (wheat, corn, sorghum, rice, sunflower, soybeans, and peanuts), thus excluding fruits, vegetables, and forage crops. The included crops, however, account for approximately $90 \%$ of the planted area in the country.

Estimates are presented on labor-hours per unit of land for both systems. As shown, reduced tillage results in about half the number of hours per hectare (soil preparation, planting, weed, and pest control, excluding harvesting).

As relates to the substitution effect $\Delta L^{S}$, the adoption of reduced tillage $(55 \%$ of planted area in 2002) allowed a reduction in the labor (as compared to the conventional tillage scenario) of 17000 workers, or $2.1 \%$ of the reported (permanent workers + contract work) agricultural labor force for that year (801 000). In turn, the expansion effect $\Delta L^{E}$ resulted in an increase of 27000 workers from additional crop area, minus 26000 from the reduction in animal stocks during the period. The net figure for $\Delta L^{S}+\Delta L^{E}$ is 16000 fewer workers in 2018 as compared to 2002. This figure represents $2.0 \%$ of the existing agricultural labor force in 2002, and $5.3 \%$ of the reduction (331000 workers) in ag labor force occurring from 2002 to 2018.

In conclusion, the observed reductions of labor use between 2002 and 2018 are only partially explained by the adoption of reduced tillage systems. Even allow- 
ing for errors in the technical coefficients used in the calculations (many of them crude estimates), it is highly unlikely that the reduced tillage systems per-se are responsible for the large falls in the reported labor in the primary agricultural sector.

Table 4. Changes in Labor Use Resulting from Reduced Tillage

\begin{tabular}{lccc}
\hline & & 2002 & 2018 \\
\hline Planted area & million hectares & 25.0 & 35.0 \\
\hline Share conventional tillage & $\%$ & 0.45 & 0.10 \\
\hline Share reduced tillage & $\%$ & 0.55 & 0.90 \\
\hline Conventional tillage area & million hectares & 11.3 & 3.5 \\
\hline Reduced tillage area & million hectares & 13.8 & 31.5 \\
\hline Labor requirement in conventional tillage & Hrs/ha & 3.5 & 3.5 \\
\hline Labor requirement in reduced tillage & Hrs/ha & 2.0 & 2.0 \\
\hline (A) Substitution effect & Person-years & & -17000 \\
\hline (B) Expansion effect (1) & Person-years & & 27000 \\
\hline (additional labor from additional crop area) & & & \\
\hline (C) Expansion effect (2) & Person-years & -26000 \\
\hline (reduced labor from reduced livestock) & & & \\
\hline Net effect = (A) + (B) + (C) & Person-years & -16000 \\
\hline
\end{tabular}

Sources: Planted Area Ministerio de Agricultura.

Technical coefficients: own calculations based on trade publications.

\section{II.3. H3: Scale/Size Relationships}

The scale returns resulting from the consolidation of resources from a larger to a smaller number of farms can account for the larger output of a given stock of resources. However, it cannot explain the decreasing use of farm labor: the "scale" concept refers to equi-proportional changes in input (including labor) use. Economies of scale would result in a reduction in the number of farm units, but not in the outflow of resources (labor in particular) from the agricultural sector to others of the economy. This is particularly true if the sector output is 
tradeable and, thus, the increased volume of production from farm consolidation does not result in a fall in output prices. The analysis of the impact of the farm size on labor use therefore requires attention to be focused on input proportions and not pure "scale" effects.

In the 1988-2002 period, farm numbers in Argentina fell by $1.7 \%$ per year (Table 5). The reduction in farm numbers slightly grew by $1.8 \%$ between 2002 and 2018. The reduction in farm numbers was somewhat higher in the "non-pampean" region than in the "pampean" one. As a result of these changes, in the 2002-2018 period, the farm size (measured in area per farm) increased $35-40 \%$. The increased farm size is a result of optimizing decisions, in particular, reductions in costs and improved perspectives for profit and further firm growth. While several factors may result in a negative relation between the farm size and average costs, an important one to be considered are the savings associated with higher capacity machines.

Table 5. Farm Numbers, Selected Provinces

\begin{tabular}{lcccccc}
\hline & \multirow{2}{*}{1988} & 2002 & 2018 & $\begin{array}{c}1988 / \\
2002\end{array}$ & $\begin{array}{c}2002 / \\
2018\end{array}$ & $\begin{array}{c}1988 / \\
2018\end{array}$ \\
\hline & \multicolumn{5}{c}{ farm numbers } & \multicolumn{3}{c}{$\Delta / \mathbf{y r}(\%)$} \\
\hline Total & 421221 & 333533 & 250881 & -1.7 & -1.8 & -1.7 \\
\hline Pradera Pampeana (1) & 189000 & 134000 & 98000 & -2.4 & -1.9 & -2.2 \\
\hline $\begin{array}{l}\text { Selected "Zona Extra- } \\
\text { Pampeana" provinces (2) }\end{array}$ & 68000 & 58000 & 40000 & -1.1 & -2.3 & -1.8 \\
\hline
\end{tabular}

(1): Provinces of Buenos Aires, Córdoba, Entre Ríos, La Pampa, and Santa Fe.

(2): Provinces of Chaco, Salta, Santiago del Estero, and Tucumán.

Source: CNA 1988, 2002, and 2018.

Larger farm sizes facilitate (and, in turn, are the result of) changes in the types of capital used and, in particular, in the ratio between capital and labor input. Moreover, different types of capital may allow an increase in the $K / L$ ratio without a corresponding change in the amount of $K$. Instead $K / L$ may increase due only (or mostly) to a reduction in $L$. 
Let each unit of farm machinery $K^{A}$ produce twice the flow of output services as machinery $K^{B}$. If a farm substitutes one unit of $K^{A}$ for two units of $K^{B}$, the total capital remains unchanged. However, labor use under $K^{A}$ will be half as that of $2 K^{B}$, if $K^{A}$ "requires" only one worker, the same labor requirement of each of 2 units of $K^{B}$ it replaces. Formally:

$$
Q^{B}=\min \left[L / 2, K^{B} / 2\right]=Q^{A} \min \left[L, K^{A}\right] \text { where } K^{A}=2 K^{B}
$$

The issue here is thus not capital/labor substitution, but differences in the organization of production. The trend towards larger machinery may be catalogued as "technical change", if machinery is not only larger, but incorporates features not found in smaller versions. A good example of this is reduced-tillage planters, sprayers as well as computerized monitoring systems that are only cost-effective in high-output agricultural machines such as tractors and combines.

Figure 3 shows (2002-2018 period) the percentage of total tractor and combine horsepower stocks represented by the two largest categories of each of these types of machines (see Appendix for details).

Figure 3. Changes in Machinery Size (\% of Total HPs represented by the largest-sized machines)

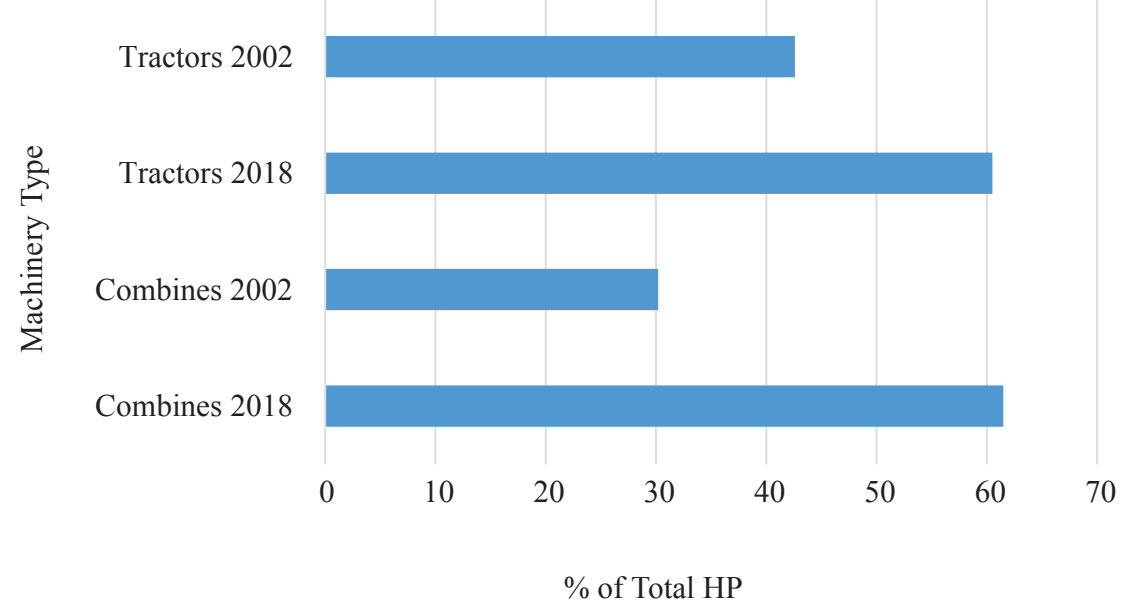

Source: Own calculations based on CNA 2002 and 2018. 
Results indicate that "large" tractors accounted for $43 \%$ of the total HP in 2002 , increasing to $60 \%$ in 2018 . In the case of combines, "large" units accounted for $30 \%$ of the total HP in 2002 and $62 \%$ in 2018 . Higher capacity machines thus allow reductions in labor costs without necessarily increasing the capital-labor ratio ("large" machines replace "smaller" ones, leaving total capital unchanged). In sum, in contrast with the inconclusive evidence resulting from hypothesis $\mathrm{H} 2$, $\mathrm{H} 3$ appears to reasonably explain the observed reductions in labor use that occurred in the Argentine agriculture.

\section{CROP YIELDS AS A DETERMINANT OF MACHINERY SIZE}

As suggested above, not only the "amounts" of capital, but also the specific forms this capital takes affect cost-minimizing input combinations. The last decades have witnessed a virtual revolution as relates to agricultural machinery. Improvements not only occurred in the basic design (e.g., reduced tillage planters allowing higher planting speed, improved precision, fertilizer placement), but also in the introduction of real-time monitoring of crop conditions, soil fertility, and other aspects. These technologies are not scale neutral, but involve fixed costs both as relates to hardware, software (where applicable) as well as technological know-how on the part of the farmer.

The case of modern harvesters illustrates some of the issues involved. A steady trend towards higher output machines has been evident: in the early 1970s, engines of harvesters produced by major manufacturers averaged 140-150 HP. In contrast, in 2010, harvester engines averaged 400 HP (Méndez, Velez, \& Scaramuzza, 2014). Larger combines allow higher throughput and reduced labor costs.

The question may be asked on what constraints exist on the machinery size. The answer lies in that there are technical constraints on both the "practical" width of cutting platforms and, in particular, the speed at which the machine can travel over ground. Harvest losses increase with harvester speed, thus effective use of more powerful combines is only possible with higher crop yields.

Differences in yields are expected to vary according to both technical (TE) as well as allocative $(A E)$ efficiency at the farm level. $T E$ will increase yields as a result of higher output levels per unit of input. However, an upward shift in the production function (increased $T E$ ) will generally increase input marginal productivity as these shifts result also in changes in the slope as well as in output for every input level. This will trigger higher input levels and, thus, additional yields 
independent of those resulting only from increasing $T E$. The result is improved conditions for better-quality and higher-capacity machines, larger farm sizes, and reduced labor for a given amount of capital. The pattern that seems to emerge is thus one of higher crop yields facilitating higher-capacity machinery (in particular combines) to work efficiently.

The implications of the above are the following. First, labor-savings may be achieved by the use of "larger" capital inputs (tractors, combines, planters, forage equipment) as these allow a given capital stock to be combined with a reduced level of labor services. Second, cost-efficiency of larger machines increases with the farm size: even if the farmer contracts machinery services instead of purchasing equipment, coordination costs are reduced — at least up to a point- when a

given contractor supplies services to a smaller number of clients. Of course, if the farmer purchases equipment instead of renting it, the case for a larger farm unit is even stronger.

Lastly, interactions exist between farm-level productivity and the choice of the machinery size: higher yields reduce average operating costs of larger harvesters. Similarly - and given all else equal — more frequent or increased volume of fertilizer or pesticide applications, or the need for more timely production practices increase the optimal machinery size and, therefore, indirectly, the farm size as well. "Technical change", interpreted as an increased volume of a given stock of resources, is, thus, an additional factor explaining the growth in the machinery size and, as a consequence of these changes, reducing the demand for labor services.

\section{FINAL COMMENTS}

Evidence presented here suggest a "best guess" for the elasticity of substitution between capital and labor inputs ranging from 1 for the pradera pampeana to 2 for the extra-pampean zone, and averaging about 1.5 for the country as a whole. These values are in line with those resulting from studies conducted, for example, in Brazil and the U.S. Although substitution possibilities between capital and labor appear quite high, they probably do not account for all of the observed reduction in labor use that took place in the 2002-2018 period.

Labor-savings associated with reduced tillage are a potential determinant of additional shifts in the demand for labor. In the case analyzed here, however, reduced tillage — while saving on labor on a per-hectare basis - has its effect dampened due to an increase in the crop area that resulted from this technology: 
even abstracting from this issue, per-hectare labor savings alone cannot account for the large reduction in the labor input observed in the Argentine agricultural sector. Other factors are operative.

Increased capacity of agricultural machinery seems to be the most important variable explaining the falling demand for labor. In Argentina, total capital, at least as measured by a "horsepower index," appears to have experienced relatively modest increases -in particular as compared to decreases in the use of labor (the increase in the use of capital was $4.5 \%$ country-wide, $7.6 \%$ in the "pradera pampeana," and $10.3 \%$ in the non-pampean provinces analyzed here). The important reduction $(20.9 \%)$ of the capital input in the provinces not analyzed here explains that the country-wide capital increase is lower than that of the pampean and nonpampean provinces included in the study.

Evidence is then not in favor of a substantial increase in the "conventional" ( i.e., horsepower index) capital, but on the types of capital employed: the share that machines of larger capacity represent of the total capital stock increased significantly during the last decade and a half. As argued above, larger machines allow labor savings - at least in some size ranges - as labor input per machine does not change proportionally with the output capacity of the machine.

It should be emphasized that larger machines (in particular newer ones) incorporate features not present to the same degree in the ones of smaller size. The "technical change" in capital inputs is, therefore, an additional factor that adds to the "conventional" labor saving resulting from the machine size per se.

This paper argues that there are linkages between the production per unit of land and the optimal machinery size: higher yields increase the cost efficiency of higher output machines (in particular, harvesters, but probably also planters and other pieces of equipment). A causal chain then exists linking better management with higher yields and, thus, larger machine sizes. Larger machines, in turn, act as a catalyst for the increase in the farm size. 


\section{APPENDIX: DATA AND CALCULATIONS}

\section{Labor Input}

The data source is the Censo Nacional Agropecuario (CNA) 2002 and 2018. Census data does not report labor flows (e.g., days worked by family and hired laborers per year), but stocks of "permanent" labor. This measure is an imperfect estimate of the actual labor supplied due to: (a) the varying degree of labor utilization, (b) the non-inclusion of seasonal labor (of particular importance in labor-intensive activities such as fruits and vegetables), and (c) the non-inclusion of not including labor supplied by custom contractors. The approach used adds an estimate of labor supplied by contractors to the permanent labor figures:

$$
L^{T}=L^{C N A}+L^{C o}
$$

Where:

$L^{T} \quad=$ Total labor input (persons/year).

$L^{C N A}=$ Labor input (persons/year) reported in CNA.

$L^{C o}=$ Estimate of labor from contracted services reported in CNA.

And:

$$
L^{C o}=\left[A^{C o} * t_{2}\right] / t_{1}
$$

Where:

$A^{C O}=$ total land area (hectares) receiving contract work.

$t_{l}=$ estimate of effective (e.g., "net on the machine") hours of labor per worker.

$t_{2}=$ estimate of per-hectare labor hours of labor used in contract work (per-hectare average of different implements).

Coefficients used were $t 1=792 \mathrm{hrs}, t 2=0.96 \mathrm{hrs} / \mathrm{ha}$. $S^{H}$ was obtained from the CNA. An identical procedure was used for the 2002 and 2018 censuses.

\section{Capital Input}

The capital input was derived by a (weighted) sum of tractor plus combine (harvester) horse-power. The following correction was used for age (vintage) of tractors and combines: $0.80^{(\mathrm{t}-1)}$ where: 


\begin{tabular}{llll}
$\begin{array}{l}\text { Machine age (years) } \\
-\end{array}$ & \multicolumn{2}{c}{$\mathrm{t}$ Correction factor } \\
$<5$ & & 1 & 1.00 \\
$5-9$ & 2 & 0.80 & \\
$10-14$ & 3 & 0.64 & \\
$>15$ and + & & 4 & 0.51 \\
\end{tabular}

The above hyperbolic decay function was used in order to capture advances in "quality" (sensors, GPS, automatization). After adjustment for vintage, the total capital was then calculated as the weighted sum of tractor and combine horsepower:

$$
\begin{aligned}
& K=\text { Adjusted Tractor Horsepower } *(1 / 0.5)+ \\
& \text { Adjusted Combine Horsepower } *(1 / 0.3)
\end{aligned}
$$

The weights attempt to approximate the "expansion" of machinery horsepower to the total capital associated with each machinery: i.e., total cost of a combine + ancillary equipment used for harvest is 3.3 times the cost of the combine's engine.

\section{Relative Labor/Capital Price Ratio (w/r)}

Two alternative data sources were used to obtain estimates. Index 1 and Index 2, as discussed in the text, were obtained from the Margenes Agropecuarios publication. Index 3 was obtained from the Agroseries Online data bank of the Asociación Argentina de Grupos CREA (AACREA).

Index 1: Ratio [per-hectare labor costs/price of a tractor (120 hp)]

Index 2: Ratio [per-hectare labor costs/non-labor per-hectare machinery operating costs]

Index 3: Ratio [monthly labor wage and non-labor/per-hectare machinery operating costs]

Impact of Reduced Tillage on Labor Use

Substitution Effect:

$$
\Delta L^{S}=\left\{A_{t 0}\left[\left(S_{t 1}^{C} L^{C}+S_{t 1}^{R T} L^{R T}\right)-\left(S_{t 0}^{C} L^{C}+S_{t 0}^{R T} L^{R T}\right)\right]\right\} / t_{1}
$$


Expansion Effect:

$\Delta L^{E}=\left\{\left[A_{t 1}-A_{t 0}\right]\left[S_{t 1}^{C} L^{C}+S_{t 1}^{R T} L^{R T}\right]-\left[L U_{t 1}-L U_{t 0}\right] L^{L}\right\} / t 1$

Total Effect:

$$
\Delta L^{T}=\Delta L^{S}+\Delta L^{E}
$$

Where:

$\Delta L^{T}=$ change in labor use resulting from reduced tillage.

$A_{t 0}=$ Crop area at $\mathrm{t}=\mathrm{t} 0$.

$A_{t 1}=$ Crop area at $\mathrm{t}=\mathrm{t} 1$.

$\mathrm{SC}^{\mathrm{C}}=$ share planted area in conventional tillage.

$\mathrm{SRT}^{\mathrm{RT}}=$ share planted area in reduced tillage.

$L^{C} \quad=$ labor per unit of land in conventional tillage.

$L^{R T}=$ labor per unit of land in reduced tillage.

$L U=$ livestock units.

$L^{L} \quad=$ labor per $L U$.

$t 1=$ effective ("on tractor") hours per year $=792 \mathrm{hrs} /$ worker.

The crop area in 2002 and 2018 were obtained from the Ministerio de Agroindustria. $L^{C}, L^{R T}$, and $L^{L}$ from trade publications and personal communications with farm advisors:

$$
\begin{array}{ll}
L^{C}(\mathrm{hrs} / \mathrm{ha}) & =3.5 \\
L^{R T}(\mathrm{hrs} / \mathrm{ha}) & =2.0 \\
L^{L}(\mathrm{hrs} / \mathrm{ha}) & =1 / 250=0.004
\end{array}
$$

Labor-hours were transformed to "person-years" assuming 1760 potential working hours per year per person, of which $75 \%$ are transformed into actual labor input flows: $1760 \times 0.75=1320 \mathrm{hrs} /$ year per person. The assumption of $75 \%$ of "efficiency" of labor use was based on lost days due to weather, travel, overhead, and other factors.

The estimation of lesser labor due to a reduction in livestock numbers $\left(L^{L}\right)$ was conducted by dividing the reduction in animal stocks ("Livestock Units", $L U$ ) by an estimate of $L U$ per unit of labor input (250 person-years per $L U$ ). 
Data for $L U$ was taken from the CNA:

Animal stocks (millions):

\begin{tabular}{lllll} 
& Beef & Sheep & Pigs & Total LU \\
2002 & 48.5 & 12.6 & 2.18 & 40.7 \\
2018 & 40.4 & 8.8 & 3.10 & 34.3 \\
\hline Change & -8.1 & -4.0 & 1.4 & 6.4
\end{tabular}

Source: CNA 2002 and 2018.

The total $L U$ equivalents was calculated as $0.80 *$ Beef $+0.10 *$ Sheep + $0.30 \times$ Pigs $^{9}$. The change in labor use was calculated dividing the change in LU by 250, an estimate of LU/person-year.

\section{REFERENCES}

Bour, J. L. (1996). Procesos de reforma del mercado de trabajo en Argentina. (Manuscrito inédito). Ciudad Autónoma de Buenos Aires: Fundación de Investigaciones Económicas Latinoamericanas (FIEL).

CREA. (2020). Agroseries Online Economía. Consultado en noviembre 2020 y recuperado de https://www.crea.org.ar/agroseries-on-line/.

Evenson, R. E. (1988). Human Capital and Agricultural Productivity Change. (Economic Growth Center, Yale University, Center Discussion Paper No. 566). Recuperado de https://www.econstor.eu/bitstream/10419/160488/1/ cdp566.pdf

Gallacher, M., \& Lema, D. (2018). Returns to Management Ability and Technical Efficiency in Argentina Dairy Farms. Paper presented at the Conference of the International Association of Agricultural Economists, Vancouver, Columbia Británica.

Gallacher, M. (2010). Capital humano y eficiencia productiva en la agricultura argentina. En L. Reca, D. Lema y C. Flood (eds.). La Agricultura Argentina: Medio Siglo de Logros y Desafios (cap. 16, pp. 391400). Buenos Aires: Universidad de Buenos Aires.

9 See https://ec.europa.eu/eurostat/statistics-explained/index.php/Glossary:Livestock_unit_(LSU) 
Gallacher, M. (2011). Returns to Managerial Ability: Dairy Farms in Argentina. (Universidad del CEMA, Serie Documentos de Trabajo No. 478). Recuperado de https://ucema.edu.ar/publicaciones/download/documentos/478.pdf

INDEC. (2021). Censo Nacional Agropecuario 2002 y 2018. Recuperado de https:// www.indec.gob.ar/indec/web/Nivel4-Tema-3-8-87

International Labor Organization. (2020). Rural and Urban Labor Markets, Different Challenges for Promoting Decent Work. (ILO, Spotlight on Work Statistics No.11). Recuperado de https://ilo.org/wcmsp5/groups/public/--dgreports/--- stat/documents/publication/wcms_757960.pdf

Márgenes Agropecuarios, 2002 and 2018, issues corresponding to the month of April of each year. Data on labor and machinery services costs (Table "Costo de siembra y pulverizacion")

Nocelli Pac, S. (2018). Evolución de la Siembra Directa en Argentina. Campaña 2016-2017. Rosario: Asociación Argentina de Productores de Siembra Directa (AAPRESID). Recuperado de https://www.aapresid.org.ar/wpcontent/uploads/2018/03/Estimacio\%CC\%81n-de-superficien-en-SD.pdf

Pisani Claro, N. \& Mazo, D. (2019). El campo argentino en números 2019. Río Cuarto, Córdoba: Fundación Agropecuaria para el Desarrollo de Argentina (FADA). Recuperado de https://fundacionfada.org/informes/el-campo-argentino-en-numeros-4/

Taboada, M., Lema, D., Maceira, N., Echeverría, H, Posse, G., Prieto, D., ...\& Mastrángelo, M. (2017). Los desafíos de la agricultura argentina: satisfacer las futuras demandas y reducir el impacto ambiental. Compilado por Fernando H. Andrade. Ciudad Autónoma de Buenos Aires: Ediciones INTA. Recuperado de https://inta.gob.ar/sites/default/files/lib_desafiosagricultura_2017_online_b.pdf

Wei, T. (2013). Estimation of substitution elasticities in agriculture. (Unpublished manuscript).

World Development Indicators (November, 2020). Data on total and agricultural labor. Recuperado de http://datatopics.worldbank.org/world-developmentindicators/

(C) 2021 por los autores; licencia no exclusiva otorgada a la revista Estudios económicos. Este artículo es de acceso abierto y distribuido bajo los términos y condiciones de una licencia Atribución-No Comercial 4.0 Internacional (CC BY-NC 4.0) de Creative Commons. Para ver una copia de esta licencia, visite http://creativecommons.org/licenses/by-nc/4.0 
